\title{
English Locative Prepositions in, on, at and Spanish Locative Prepositions en and sobre
}

Rosa Isabel Chavarría Fonseca

Universidad Nacional, Costa Rica

A number of different, even contradictory, studies have attempted to explain the differences in lexical frequency. From the research on the topic, two opposing positions can be mentioned in this study. First of all, the contrastive hypothesis has provided an important guide to the selection and sequencing of items for instruction based on the assumption that the learner's first language will have an important influence on the acquisition of a second. ${ }^{1}$ Later, the morpheme order studies have claimed that there was a universal order of acquisition which was driven by an innate learning process. Therefore, many of the grammar errors made by the learner were similar in both the first and second language. ${ }^{2}$

Notwithstanding the contradictions between these perspectives, neither was contrastive analysis able to support its strong claims, nor have the morpheme order studies offered a theoretical rationale for their findings. Rather than focusing on a single hypothesis or research, this study will examine the existing background research on the topic as different possibilities for the analysis of specific issues on second language teaching.

\footnotetext{
1. Sam Hill, Contrastive English-Spanish Grammatical Structures (Sacramento: University Press of America, 1985) 313.

2. David Nunan, Language Teaching Methodology: A Textbook for Teachers (London: Prentice Hall, 1991) 145.
} 
Of relevant importance to this study are the specific findings reported by Johnston ${ }^{3}$ on the acquisition of lexis by learners of English as a second language. In his research he suggests that the frequency of use of prepositions does not agree with the order in which these items are taught.

Many linguists and grammarians have argued the existence of the preposition as an independent part of the sentence (e.g. Vendryes, Jespersen, Nat Beckman, Hjelmslev, Sechehaye, Wagner). Others affirm that prepositions have a particular function as part of the sentence (e.g. Bello, Lenz, Alonso, Henriquez, Paul, Ljunggren). ${ }^{4}$ However, all agree that prepositions are small words full of meaning that can change space and/or time or indicate a complete variation in manner.

The major purpose of this study is to establish similarities and differences between the English locatives at, on and in, and the Spanish locatives en and sobre. The use of each of these spatial concepts will be described with examples provided of both the most prototypical concept, ${ }^{5}$ and the least prototypical concept. Parallel to the description, the Spanish locatives will be compared and contrasted with the English locatives in order to draw conclusions regarding spatial concept equivalence between the two languages.

Researchers of error analysis (e.g. Chanell) suggest that the learner's knowledge of first and second language vocabulary are linked together in their mental lexicon phonologically, semantically and associationally, and that learners can make conscious the links between these aspects. ${ }^{6}$

\footnotetext{
3. M. Johnston, Syntactic and Morphological Progressions in Learning English (Canberra: Department of Immigration and Ethnic Affairs, 1985).

4. María Luisa López, Problemas y métodos en el análisis de preposiciones (Madrid: Editorial Gredos, 1970) 223.

5. Margarita Correa-Beningfield. «Prototype and Language Transfer. The Acquisition of Some English Prepositions of Location by Spanish Speakers" in the Eighth Sec(ond Language Research Forum (Honolulu: Universidad Complutense de Madrid, 1988).

6. Nunan, 130.
} 
In this study, the use of prepositions will be understood in relation to the dimensional properties, whether subjectively or objectively conceived, of the location concerned. Reference will be made to the abstract meanings of the prepositions which are clearly related, through metaphorical connection, to their locative uses keeping the groupings that they have when used in literal reference to place. The abstract meanings of "time when" of the prepositions are to some extent parallel to the same items as positive prepositions of position, although in the time sphere there are only two dimension-types, that is "point of time" and "period of time". 7

1. $O N$ has a line/surface configuration, establishing a spatial relationship of one point to another which can either be a onedimensional object (ex.: Put your signature on this line), or represent a two-dimensional area (ex.: The fiddler is on the roof.) On implies objects touching each other. This relationship can be given on a horizontal or non-horizontal surface. $O n$ can be used with spatial but not surface elements. On is also used as preposition of 'time when' with an abstract meaning.

\subsection{Most prototypical use}

1.1.1 + surface element, + horizontal element, + touching objects

a. Put your signature on this line.

b. The fiddler is on the roof.

1.1.1.1 with roads, bridges and routes

a. He was waiting for her on the bridge.

b. She lives on Canal Street.

1.1.2 + surface element, + non-horizontal element, + touching objects

7. Randolph Quirk and Sidney Greenbaum, A Concise Grammar of Contemporary English (London: Harcourt Brace Joṿanovich, 1973). 
a. The child wrote his answer on the board.

b. The frost made patterns on the window.

1.2 Least prototypical use

1.2.1 + surface element, + attached objects

a. There is a fish on the hook.

b. We saw some apples on the tree.

1.2.2 for most modes of conveyance: large vehicles which imply the condition of being 'in transit', as well as for two-wheeled vehicles and animals used for transportation.

a. The students go to school on the bus.

b. She came on her bike despite the rain.

1.2.3 for most audio and video equipment

a. We heard the news on the radio.

b. I saw him on T.V.

1.2.4 Point of time (abstract meanings)

a. The train didn't arrive on time at the station.

b. The bell rang on time for the next lesson.

1.2.4.1 for dates and for days of the week

a. She was born on July 20, 1974.

b. We are going to Chicago on Saturday.

2. SOBRE has a line/surface configuration establishing a spatial relationship of one point to another which can either be a onedimensional object (ex.: No escriba sobre la primera línea.), or represent a two-dimensional area (ex.: Los gatos están sobre el muro.) This relationship can be given on a horizontal and non-horizontal surface. The Spanish sobre may establish two different spatial relationships: one that implies the touching of the objects in the relationship, and the other establishing a relationship of superposition of one object (or concept) over another, not necessarily implying a straight-line relationship. 
2.1 Most prototypical use

2.1.1 + surface element, + horizontal element, + touching objects

a. No escriba sobre la primera línea.

b. Los gatos están sobre el muro.

2.1.1.1 with roads, bridges and routes

a. El camión se detuvo sobre el puente.

b. El autobús iba sobre la autopista.

2.1.2 + surface element, + non-horizontal element, + touching objects

a. Los muchachos escribieron sus nombres sobre la pared.

b. El vapor dejó extraños diseños sobre el espejo.

2.2 Least prototypical use

2.2.1 + surface element, + horizontal element, - touching objects; superposition of one object over another, not touching each other, and in a direct vertical relationship, simply indicating on a higher level.

a. Para viajar a Europa hay que volar sobre el océano.

b. La lámpara cuelga sobre la mesa.

2.2.2 + surface element, - touching objects; superposition of one object over another, not touching each other, and not in a straight-line relationship. See figure 1.

Figure $1 \quad \frac{X}{Y}$

a. Cientos de golondrinas vuelan sobre los árboles.

b. Los aviones vuelan sobre las nubes. 
2.2.3 superposition of one concept over another
a. El bienestar del pueblo debe estar sobre los intereses de los gobernantes.
b. La verdad debe prevalecer sobre la mentira.

3. IN establishes an area or volume configuration, establishing a spatial relationship of one point to another which is three-dimensional (ex.: The child put the piece of glass in his pocket.) Area should be conceived of as an enclosed space. In can also take a two-dimensional object (ex.: The cow is in the field.) It may also be used to indicate a specific point in time.

\subsection{Prototypical use}

3.1.1 to indicate a relationship point-area/volume, where one object is within the confines of another object which is an enclosed space or container

a. There were more than a hundred guests in the room.

b. The child put the piece of glass in his pocket.

3.1.2 with objects indicating a relationship point-area, where one object is within the confines of the other, but not implying the meaning of container.
a. The cow is in the field.
b. The strange man was standing in the doorway.

3.1.3 with small, four-wheeled-motor vehicles

a. I saw him in his new car.

b. It was raining so she came in a taxi.

3.1.4 to indicate periods of time

3.1.4.1 with months and years

a. I moved to San Jose in 1961.

b. We visited Peru in October. 
3.1.4.2 to indicate a time within a larger period of time

a. The doctor will be back in an hour.

b. I will try to be here in the morning.

4. AT establishes a spatial relationship of one point to another that represents a dimensionless location, a mere point in relation to which the position of an object can be indicated. At can also indicate points of time. At shows such a broad range of uses that it is difficult to get at its prototypes.

4.1 Most prototypical use

4.1.1 to indicate the location where an activity takes place, but does not specify any surface or area relationship among the objects involved.

a. The concert was at the university.

b. She is at the door waiting for her turn.

4.1.2 to refer to a building in its institutional or functional aspect

a. I work at a state university.

b. It is 2 o'clock. She must be at the office now.

4.2 Least prototypical use

4.2.1 to indicate a precise place

a. She lives at 409 Campus View.

b. The Flee Market is at the corner of Seventh and Elm.

4.2.2 Points of time

4.2.2.1 to indicate a precise time that has previously been mentioned

a. At that time he was only five years old.

b. At that moment she heard a strange shriek.

4.2.2.2 to indicate clock time

a. My class starts at eight.

b. I will meet you at one o'clock. 
5. EN has such a broad range of uses that in various cases it has the property of replacing other prepositions. ${ }^{8} E n$ will be described here not only in terms of its prototypical examples, but also as a substitute of the Spanish sobre. En may be used with a) dimensionless location (ex.: El hombre extraño estaba de pie en la puerta.), b) one-dimensional objects (ex.: No escriba en la primera línea.), c) two-dimensional objects (ex.: El autobús iba en la autopista.) and d) three-dimensional objects (ex.: Lo vi en su carro nuevo.)

\subsection{Most prototypical use}

5.1.1 with objects indicating the relationship point-area/ volume, when an object is within the confines of another object

Sentences in 3.1.1, 3.1.2, and 3.1.3 can be considered as having the same meaning as the following:

a. Había más de cien invitados en el salón.

(There were more than a hundred guests in the room.)

b. El niño puso el trozo de cristal en su bolsillo.

(The child put the piece of glass in his pocket.)

c. La vaca está en el potrero.

(The cow is in the field.)

d. El hombre extraño estaba de pie en la puerta.

(The strange man was standing in the doorway.)

e. Lo vi en su carro nuevo.

(I saw him in his new car.)

f. Estaba lloviendo, por lo que ella vino en un taxi.

(It was raining, so she came in a taxi.)

5.1.2 to indicate time with months and years

Sentences in 3.1.4.1 can be considered as having the same meaning as the following:

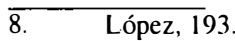



a. Me trasladé a San José en 1961. (I moved to San Jose in 1961.)
b. Visitamos Perú en octubre.
(We visited Peru in October.)

5.1.3 to indicate a time within a longer period of time

Sentences in 3.1.4.2 can be considered as having the same meaning as the following:
a. El médico regresará en una hora.
(The doctor will be back in an hour.)
b. Trataré de estar aquí en la mañana.
(I will try to be here in the morning.)

5.2 Encan replace sobre when used with the meaning of surface configuration and implying objects touching each other. This also seems to be considered the prototypical use of this spatial concept. Sentences in 2.1 are likely to have the same meaning as the following:

a. No escriba en/sobre la primera línea.

(Do not write on the first line.)

b. Los gatos están en/sobre el muro.

(The cats are on the roof.)

c. El camión se detuvo en/sobre el puente.

(The truck stopped on the bridge.)

d. El autobús iba en/sobre la autopista.

(The bus went on the highway.)

e. Los muchachos escribieron sus nombres en/sobre la pared.

(The boys wrote their names on the wall.)

f. El vapor dejó extraños diseños en/sobre el espejo.

(The steam left strange patterns on the mirror.)

5.2.1 According to 5.2, the Spanish locative en and the English locative on share the same spatial conceptual meaning since en can replace sobre when used 
with the meaning indicated above. Therefore, the following examples can be considered to have the same meaning as the sentences in 1.1:

a. Ponga su firma en/sobre esta línea.

(Put your signature on this line.)

b. El violinista está en/sobre el tejado.

(The fiddler is on the roof.)

c. Él la estaba esperando en/sobre el puente.

(He was waiting for her on the bridge.)

d. Ella vive en/sobre Canal Street.

(She lives on Canal Street.)

e. El niño escribió su respuesta en/sobre el pizarrón.

(The child wrote his answer on the board.)

f. La escarcha marcó diseños en/sobre la ventana.

(The frost made patterns on the window.)

5.3 En can also appear as: a) + spatial element, - surface element; b) with vehicles; c) for most audio and video equipment. The following sentences can be considered as the Spanish equivalent to the sentences in 1.2:

a. Hay un pez en el anzuelo.

(There is a fish on the hook.)

b. Vimos algunas manzanas en el árbol.

(We saw some apples on the tree.)

c. Los estudiantes van a la escuela en el autobús.

(The students go to school on the bus.)

d. Ella vino en su bicicleta a pesar de la lluvia.

(She came on her bike despite the rain.)

e. Escuchamos las noticias en la radio.

(We heard the news on the radio.)

f. Lo vi en la televisión.

(I saw him on T.V.) 
5.4 En can indicate a spatial relationship of one point with regard to another, not specifying any surface or area/volume element.

5.4.1 to indicate location where an activity takes place, regardless of any surface or area/volume relationship

Sentences in 4.1 can be considered as having the same meaning as the following:

a. El concierto fue en la universidad.

(The concert was at the university.)

b. Ella está en la puerta esperando su turno.

(She is at the door waiting for her turn.)

c. Trabajo en una universidad estatal.

(I work at a state university.)

d. Son las 2 de la tarde. Ella debe estar en la oficina ahora.

(It's two o'clock. She must be at the of fice now.)

5.4.2 to indicate a precise place

The following can be considered as equivalent to the sentences in 4.2.1

a. Ella vive en el 409 de Campus View.

(She lives at 409 Campus View.)

b. El Mercado de las Pulgas está en la esquina de la avenida Sétima y la calle Elm.

(The Flea Market is at the corner of Seventh and Elm.)

5.4.3 to indicate: a) a precise time that has previously been mentioned, b) a specific point of clock time

Sentence in 4.2.2.1 can be considered as having the same meaning as the following

a. En ese entonces él solo tenía cinco años.

(At that time he was only five years old.)

b. En ese momento ella escuchó un chillido extraño.

(At that moment she heard a strange shriek.) 


\section{ANALYSIS}

The Spanish locative sobre and the English locative on have the same spatial concept meaning in all of their most prototypical uses when used with the meaning of surface configuration and implying objects touching each other. On the other hand, the Spanish locative en has the property of substituting sobre and taking its place in all those cases in which sobre is used with the same spatial concept meaning as the English locative on. This gives an incidence of equivalence between $o n$ and $e n$ in six out of eight uses of $o n$.

The spatial concept at seems to share the same spatial concept meaning with the Spanish en in four out of five cases, which could be interpreted as high incidence of equivalence. However, this apparent equivalence in meaning should not be so, and correspond, instead, to the fact that both at and $e n$ are the only spatial prepositions that share a static spatial sense.

According to the examples provided, the most prototypical uses of the Spanish en seem to correspond completely to the prototypical uses of the English preposition in. These two locatives seem to have the highest correspondence, which makes them the most likely equivalents of each other.

As it can be noted, the Spanish preposition en seems to be widely used, and is likely to substitute, with equivalence in meaning, other Spanish prepositions (e.g. sobre, entre, para). ${ }^{9}$ At the same time, it seems predictable that the English locatives in, on, and at will be linked to the Spanish locative en due to the high incidence of equivalence. It was noted that in and $e n$ are the most likely equivalents due to the fact that both share all of their most prototypical uses.

How is this going to affect Spanish speakers learning English? Are they going to overextend even more the already significant frequency of the English preposition in reported by Johnston, due to

$\overline{9 . \quad \text { López, } 192 .}$ 
its high correspondence with the Spanish preposition en? CorreaBeningfield attempts to answer these questions in her study and concludes that if the prototypical concept of en corresponds to English in in its meaning, then not only the appropriate use of in will be found in a sentence like:
a. Quedan tres galletas en el frasco.
b. There are three cookies left in the jar.

but heavy reliance on in will also be found, where on and at would be appropriate:

a. Ernesto tiene un yeso en la pierna derecha.

b. Ernesto has got a cast in his right leg. (on)

a. Encontré a Susana en la estación de autobuses.

b. I met Susana in the bus stop. (at)

These observations agree with Johnston's reports on the topic. Even though the prepositions in, on, at are taught very early in standard textbooks (e.g. Interactions One, Chapter 2; and New Interchange I, Unit 2), the frequency use varies significantly. Johnston reports the following frequency counts: in (506), at (57) and on (19).

The preposition in is likely to be the most equivalent to the Spanish en. The overgeneralization of the preposition en in Spanish and the equivalence of this locative with the English in, may affect the acquisition of English as a foreign language in an overgeneralization of the preposition in even in those cases where this preposition is not suitable.

\section{SUGGESTED STRATEGIES FOR TEACHING ENGLISH SPATIAL PREPOSITIONS IN, ON AND $A T$}

The teaching strategies suggested below follow the Language Teaching Approach. It is important to note that the aim of these 
strategies is to enhance comprehension of the concepts rather than to increase frequency of use.

- Stimulate the learner's awareness of the existence of different spatial concepts, and the particular spatial relationship between objects that each concept establishes (Nunan 1991: 149). Through the use of realia and/or visual aids, the instructor can exemplify the main relationships established by the spatial prepositions point-point, point-line/surface, and point-area/volume.

- Encourage the learner's ability to match the new spatial relationships with the correct representation in the target language.

- Introduce closely related concepts separately (e.g. in, at). This will help prevent confusion in the learner when trying to determine when it is appropriate to use one concept rather than another at this first stage of second language acquisition. ${ }^{10}$

- Introduce first the spatial relationship which lacks equivalence in the learner's native language. In this particular case, the English locative at, as a spatial concept, is not present in Spanish.

- Provide enough opportunities for the learners to practice using the less familiar locative prepositions. Even though learners are incapable of using a particular lexical item at the time they are taught, systematic exposure over a period of time can encourage acquisition in the long run. ${ }^{11}$

10. Numan, 148.

11. Numan, 148. 